\title{
ВПЛИВ КРАНІОСКЕЛЕТНОЇ ТРАВМИ НА ДИНАМІКУ ЕНЗИМНОЇ ЛАНКИ АНТИОКСИДАНТНОГО ЗАХИСТУ В КІРКОВОМУ І МОЗКОВОМУ ШАРАХ НИРКИ ЗА УМОВ ДВОБІЧНОГО ВИДАЛЕННЯ ГОНАД У ПЕРІОД ПІЗНІХ ПРОЯВІВ ТРАВМАТИЧНОЇ ХВОРОБИ
}

\begin{abstract}
Вплив краніоскелетної травми на динаміку ензимної ланки антиоксидантного захисту в кірковому і мозковому шарах нирки за умов двобічного видалення гонад у період пізніх проявів травматичної хворобИ
\end{abstract}

\section{І. І. Луців, А. А. Гудима, Д. В. Попович}

Тернопільський національний медичний університет імені І. Я. Горбачевського МОЗ України

Резюме. Останніми роками відмічають значне зростання частки жінок у постменопаузальному періоді. Природня інволюція, в основі якої лежить зниження рівня естрогенів, суттєво змінює реактивність i резистентність організму жінки до різноманітних сракторів навколишнього середовища. Однак до останнього часу поза увагою дослідників залишається дослідження ролі дефріциту естрогенів у порушенні антиоксидантного захисту за умов травматичної хвороби, що сприяло б пошуку напрямків патогенетично обгрунтованої корекції.

Мета дослідження - з'ясувати вплив двобічної оваріоектомії на ензимну ланку антиоксидантного захисту в кірковому і мозковому шарах нирки у пізній період краніоскелетної травми (КСТ).

Матеріали і методи. Експерименти виконано на 54 нелінійних білих щурах-самках масою 200-220 г. Гіпоестрогенний стан виконували шляхом оперативного видалення гонад із подальшим моделювання КСТ. Через 1 і 2 місяці посттравматичного періоду в кірковому та мозковому шарах нирки визначали суперосиддисмутазу (СОД) та каталазну активність.

Результати. Через 1 місяць посттравматичного періоду в тварин без гонадектомії СОД- і каталазна активність кіркового і мозкового шарів нирки істотно знижувалися порівняно з контролем. Через 2 місяці експерименту досліджувані ензими нормалізувалися, що вказує на домінування в організмі саногенних механізмів. Нанесення травми гонадектомованим тваринам супроводжувалося більшим пригніченням СОД- і каталазної активності кіркового і мозкового шарів нирки через 1 місяць посттравматичного періоду. На такому ж рівні досліджувані ензими залишалися й через 2 місяці експерименту.

Висновки. В умовах краніоскелетної травми через 1 місяць посттравматичного періоду в кірковому $i$ мозковому шарах нирки відмічають порушення ензимної СІ. І. Луців та ін., 2021
ISSN 2706-6282(print) ISSN 2706-6290(online)
The influence of cranioskeletal injury on the dynamics of the enzyme link of antioxidant protection in the renal cortex and medulla under bilateral removal of the gonades during late manifestations of traumatic disease

\section{I. Lutsiv, A. A. Hudyma, D. V. Popovych \\ I. Horbachevsky Ternopil National Medical University}

e-mail: arsgudyma@gmail.com.

Summary. In recent years, there has been a significant increase in the share of women in the postmenopausal period. Natural involution, which is based on lower estrogen levels, significantly changes the reactivity and resistance of a woman's body to various environmental factors. However, until recently, researchers have ignored the study of the role of estrogen deficiency in the violation of antioxidant protection in the conditions of traumatic illness, which would contribute to the search for directions of pathogenetically justified correction.

The aim of the study - to determine the effect of bilateral ovariectomy on the enzymatic link of antioxidant protection in the renal cortex and medulla in the late period of cranioskeletal injury (CSI).

Materials and Methods. The experiments were performed on 54 nonlinear white female rats weighing 200-220 g. The hypoestrogenic state was performed by surgical removal of the gonads with subsequent simulation of CSI. After 1 and 2 months of the posttraumatic period, superoxide dismutase (SOD) and catalase activity were determined in the cortex and cerebral layers of the kidney.

Results. After 1 month of the post-traumatic period in animals without gonadectomy SOD and catalase activity of the renal cortex and medulla was significantly reduced compared with the control. After 2 months of the experiment, the studied enzymes were normalized, which indicates the dominance of sanogenic mechanisms in the body. Injury to gonadectomized animals was accompanied by greater inhibition of SOD and catalase activity of the renal cortex and medulla after 1 month of the post-traumatic period. The studied enzymes remained at the same level after 2 months of the experiment.

Conclusions. In the conditions of cranioskeletal trauma after 1 month of the post-traumatic period in the renal cortex and medulla there is a violation of the enzymatic link of 
ланки антиоксидантного захисту, яке виявляють зниженням, порівняно з контролем, СОД- та каталазноі активності. В гонадектомованих щурів виявлені порушення сутmєво більші й не стихають через 2 місяці експерименту, що вказує на вагому роль антиоксидантної дії естрогенів у патогенезі травматичної хвороби.

Ключові слова: гонадектомія; краніоскелетна травма; супероксиддисмутаза; каталаза; нирки.

\section{ВСТУП}

Останніми роками у високорозвинених країнах світу відмічають значне зростання частки жінок у постменопаузальному періоді. Природня інволюція, в основі якої лежить зниження рівня естрогенів, суттєво змінює реактивність і резистентність організму жінки до різноманітних фракторів навколишнього середовища [1]. Одночасно відмічають і зростання рівня травматизму, який належить до основної причини смерті серед чоловіків працездатного віку, а невдовзі, за даними ВОО3, торкнеться осіб різної статі усіх вікових груп [2]. Як стверджують автори, сучасна травма характеризується зростанням частки тяжких поєднаних і множинних ушкоджень, які характеризуються розвитком травматичної хвороби з ураженням систем і органів, віддалених від місця безпосереднього ураження. Причиною смерті за таких умов є розвиток поліорганної недостатності [3].

Пусковим моментом розвитку дисорункції життєво важливих органів за умов травматичної хвороби є активація процесів вільнорадикального окиснення, яка за умов виснаження антиоксидантного захисту призводить до системної мембранопатії 3 втратою мембранозалежних функцій $[4,5]$.

В поодиноких експериментальних дослідженнях показано, що за умов гіпоестрогенного стану, зумовленого двобічною оваріектомією, нанесення краніоскелетної травми супроводжувалося посиленням процесів ліпідної пероксидації в печінці на тлі виснаження антиоксидантного захисту й не стихало в період пізніх проявів травматичної хвороби [6]. Однак до останнього часу поза увагою дослідників залишається вивчення ролі дефіциту естрогенів у порушенні антиоксидантного захисту за умов травматичної хвороби, що сприяло б пошуку напрямків патогенетично обґрунтованої корекції.

Метою дослідження було з'ясувати вплив двобічної оваріоектомії на ензимну ланку антиоксидантного захисту в кірковому і мозковому шарах нирки у пізній період краніоскелетної травми.

\section{МАТЕРІАЛИ I МЕТОДИ}

Експерименти виконано на 54 нелінійних білих щурах-самках масою 200-220 г. Модель гіпоестрогенного стану виконували шляхом оперативного antioxidant protection, which is manifested by a decrease compared to the control of SOD and catalase activity. In gonadectomized rats, the detected disorders are significantly larger and do not subside after 2 months of the experiment, which indicates the important role of the antioxidant action of estrogen in the pathogenesis of traumatic disease.

Key words: gonadectomy; cranioskeletal injury; superoxide dismutase; catalase; kidneys.

видалення гонад [7]. Через 1 місяць з моменту видалення гонад у тварин моделювали краніоскелетну травму шляхом поступового нанесення дозованого удару по черепу 3 досягненням закритої черепно-мозкової травми середнього ступеня тяжкості та дозованого удару по стегну ударним пристроєм 3 клиноподібною насадкою 3 досягненням закритого перелому стегна [8]. У групі порівняння зазначені травми моделювали у здорових тварин. Контрольну групу склали інтактні тварини та тварини із остеопорозом через 1 місяць після видалення гонад, яких не травмували.

У контрольній групі та через 1 і 2 місяці посттравматичного періоду в кірковому та мозковому шарах нирки дослідних тварин визначали супероксиддисмутазну активність (СОД-активність) [9] та каталазну активність [10], які належать до першої ланки знешкодження активних фрорм оксигену (АФО).

Під час роботи з лабораторними тваринами дотримувались міжнародних вимог про гуманне поводження з тваринами відповідно до правил Європейської конвенції захисту хребетних тварин, яких використовують 3 експериментальною та іншою науковою метою (Страсбург, 1986). Усі оперативні втручання та нанесення травм здійснювалося в умовах тіопентал-натрієвого наркозу (40 мг·кг-1). Евтаназію щурів проводили методом тотального кровопускання з серця

Статистичний аналіз отриманих результатів проводили з використанням критерію Манна - Уїтні у програмному пакеті STATISTICA 10.0 («StatSoft, Inc.», США).

\section{РЕЗУЛЬТАТИ Й ОБГОВОРЕННЯ}

Як видно 3 таблиці 1 у контрольній групі щурів без видалення гонад відмінності СОД-активності у кірковому і мозковому шарах нирки були статистично не значущі ( $>00,05)$. Разом з тим, у групі тварин із видаленими гонадами СОД-активність у мозковому шарі нирки була статистично вірогідно меншою, ніж у кірковому (на 13,1 \%, p<0,05).

Через 1 місяць після моделювання краніоскелетної травми у тварин без видалення гонад СОДактивність кіркового шару нирок, порівняно з контролем, знижувалася (на 54,0 \%, p<0,05), проте через 2 місяці експерименту показник зростав (на 45,8 \% 
Таблиця 1. Активність СОД у кірковому та мозковому шарах нирки (ум.од. мг $^{-1}$ ) в динаміці краніоскелетної травми у тварин із двобічною оваріектомією (Me (LQ; UQ)) - медіана (нижній і верхній квартилі)

\begin{tabular}{|c|c|c|c|c|}
\hline \multirow{2}{*}{ Умови експерименту } & \multirow{2}{*}{ Вид травми } & \multirow{2}{*}{ Контроль } & \multicolumn{2}{|c|}{ Термін спостереження } \\
\hline & & & 1 місяць & 2 місяць \\
\hline \multirow[t]{2}{*}{ Без видалення гонад } & Кірковий шар & $\begin{array}{c}0,75 \\
(0,69 ; 0,81) \\
(n=6)\end{array}$ & $\begin{array}{c}0,48^{*} \\
(0,45 ; 0,51) \\
(n=6)\end{array}$ & $\begin{array}{c}0,70^{\wedge} \\
(0,68 ; 0,75) \\
(n=9)\end{array}$ \\
\hline & Мозковий шар & $\begin{array}{c}0,83 \\
(0,82 ; 0,86) \\
(n=6)\end{array}$ & $\begin{array}{c}0,45^{*} \\
(0,42 ; 0,47) \\
(n=6)\end{array}$ & $\begin{array}{c}0,76^{\star \wedge} \\
(0,75 ; 0,78) \\
(n=9)\end{array}$ \\
\hline \multirow[t]{2}{*}{ Видалення гонад } & Кірковий шар & $\begin{array}{c}0,61 \\
(0,61 ; 0,63) \\
(n=6)\end{array}$ & $\begin{array}{c}0,46^{*} \\
(0,45 ; 0,47) \\
(n=7)\end{array}$ & $\begin{array}{c}0,48^{\star} \\
(0,46 ; 0,48) \\
(n=6)\end{array}$ \\
\hline & Мозковий шар & $\begin{array}{c}0,53^{\#} \\
(0,49 ; 0,58) \\
(n=6)\end{array}$ & $\begin{array}{c}0,38^{\star \#} \\
(0,37 ; 0,40) \\
(n=7)\end{array}$ & $\begin{array}{c}0,39^{* \#} \\
(0,37 ; 0,40) \\
(n=6)\end{array}$ \\
\hline \multicolumn{2}{|l|}{$p_{1}$} & $<0,05$ & $>0,05$ & $<0,05$ \\
\hline \multicolumn{2}{|l|}{$\mathrm{p}_{2}$} & $<0,05$ & $<0,05$ & $<0,05$ \\
\hline
\end{tabular}

Примітки: тут і в табл. 2:

$1)^{*}$ - відмінності показника стосовно контрольної групи статистично вірогідні $(p<0,05)$;

2) \# - відмінності показника між кірковим і мозковим шаром нирки у групах тварин із видаленням гонад і без видалення статистично вірогідні $(\mathrm{p}<0,05)$;

3) ^ - відмінності показника між 1 і 2 місяцями експерименту статистично вірогідні $(p<0,05)$;

4) $\mathrm{p}_{1}$ - вірогідність відмінностей показника у кірковому шарі нирки між групами тварин із видаленням гонад і без видалення;

5) $\mathrm{p}_{2}$ - вірогідність відмінностей показника у мозковому шарі нирки між групами тварин із видаленням гонад і без видалення.

порівняно з попереднім терміном спостереження, p<0,05) і досягав рівня контролю (p>0,05). У мозковому шарі нирок динаміка СОД-активності була подібною: через 1 місяць показник знижувався, порівняно $з$ контролем (на 45,8 \%, р<0,05), в подальшому зростав і через 2 місяці експерименту перевищував попередній термін на 68,9 \% $(p<0,05)$, проте не досягав рівня контролю $(p<0,05)$. Порівняння СОД-активності між кірковим і мозковим шарами нирки в динаміці посттравматичного періоду в тварин без видалення гонад не виявило істотних відмінностей ні через 1 , ні через 2 місяці експерименту ( $p>0,05)$.

У групі тварин з видаленням гонад у кірковому шарі нирок СОД-активність через 1 місяць посттравматичного періоду знижувалася, порівняно з контролем, на $24,6 \%(p<0,05)$ й залишалася на практично такому ж рівні й через 2 місяці експерименту $(p>0,05)$. У мозковому шарі нирки виявлено аналогічну закономірність: через 1 місяць посттравматичного періоду показник, порівняно з контролем, знижувався (на $28,3 \%, p<0,05)$ й на такому ж рівні залишався до 2 місяця експерименту ( $>>0,05)$. Порівняння СОДактивності між кірковим і мозковим шарами нирки в динаміці посттравматичного періоду у тварин з видаленням гонад виявило, що у мозковому шарі нирки досліджуваний показник був істотно меншим, ніж у кірковому в усі терміни посттравматичного періоду (відповідно на 17,4 та 18,8 \%, р<0,05).

Звертає на себе увагу той фракт, що за умов видалення гонад, порівняно з тваринами без видалення гонад, СОД-активність у кірковому шарі нирки була статистично вірогідно меншою у контролі та через 2 місяці посттравматичного періоду (відповідно на 18,6 та 31,4 \%, $\left.\mathrm{p}_{1}<0,05\right)$, а у мозковому шарі - у контролі та в усі терміни посттравматичного періоду (відповідно на 36,$1 ; 15,6$ та $48,7 \%, p_{2}<0,05$ ).

Результати аналізу каталазної активності показали (табл. 2), що у контролі в тварин без видалення гонад каталазна активність була істотно більшою у мозковому шарі порівняно з кірковим (на $12,8 \%, p<0,05)$. Водночас, у щурів із видаленими гонадами каталазна активність у мозковому шарі нирки, навпаки, була істотно меншою, ніж у кірковому (на 13,8 \%, p<0,05).

Після моделювання краніоскелетної травми каталазна активність у щурів без видалення гонад у кірковому і мозковому шарах нирки, порівняно 3 контролем, істотно знижувалася (відповідно на 23,9 та 43,2\%, p<0,05). Через 2 місяці посттравматичного періоду показник в обох досліджуваних шарах нирки істотно зростав, порівняно з попереднім терміном спостереження (відповідно на 16,8 та 68,0\%, $\mathrm{p}<0,05)$, та досягав рівня контролю $(\mathrm{p}>0,05)$. Порівняння каталазної активності у кірковому і мозковому шарах нирки в ході посттравматичного періоду у тварин без видалення гонад показало, що через 1 місяць експерименту відмінності виявилися статистично не вірогідними ( $>00,05)$. Водночас, через 2 місяці експерименту каталазна активність у мозковому шарі нирки ставала істотно більшою, ніж у мозковому (на 21,2 \%, p<0,05). 
Таблиця 2. Активність каталази у кірковому та мозковому шарах нирки (мккат·кг-1) в динаміці краніоскелетної травми у тварин із двобічною оваріектомією (Me (LQ; UQ)) - медіана (нижній і верхній квартилі)

\begin{tabular}{|c|c|c|c|c|}
\hline \multirow{2}{*}{ Умови експерименту } & \multirow{2}{*}{ Вид травми } & \multirow{2}{*}{ Контроль } & \multicolumn{2}{|c|}{ Термін спостереження } \\
\hline & & & 1 місяць & 2 місяць \\
\hline \multirow[t]{2}{*}{ Без видалення гонад } & Кірковий шар & $\begin{array}{c}1,17 \\
(1,06 ; 1,24) \\
(n=6)\end{array}$ & $\begin{array}{c}0,89^{*} \\
(0,79 ; 0,93) \\
(n=6)\end{array}$ & $\begin{array}{c}1,04^{\wedge} \\
(0,92 ; 1,08) \\
(n=9)\end{array}$ \\
\hline & Мозковий шар & $\begin{array}{c}1,32^{\#} \\
(1,29 ; 1,42) \\
(n=6)\end{array}$ & $\begin{array}{c}0,75^{\star} \\
(0,59 ; 0,78) \\
(n=6)\end{array}$ & $\begin{array}{c}1,26^{\#^{\wedge}} \\
(1,20 ; 1,32) \\
(n=9)\end{array}$ \\
\hline \multirow[t]{2}{*}{ Видалення гонад } & Кірковий шар & $\begin{array}{c}0,94 \\
(0,88 ; 1,08) \\
(n=6)\end{array}$ & $\begin{array}{c}0,61^{\star} \\
(0,58 ; 0,68) \\
(n=7)\end{array}$ & $\begin{array}{c}0,59^{*} \\
(0,52 ; 0,60) \\
(n=6)\end{array}$ \\
\hline & Мозковий шар & $\begin{array}{c}0,81^{\#} \\
(0,79 ; 0,94) \\
(n=6)\end{array}$ & $\begin{array}{c}0,52^{\star \#} \\
(0,49 ; 0,54) \\
(n=7)\end{array}$ & $\begin{array}{c}0,54^{*} \\
(0,51 ; 0,56) \\
(n=6)\end{array}$ \\
\hline \multicolumn{2}{|l|}{$p_{1}$} & $>0,05$ & $<0,05$ & $<0,05$ \\
\hline \multicolumn{2}{|l|}{$\mathrm{p}_{2}$} & $<0,05$ & $<0,05$ & $<0,05$ \\
\hline
\end{tabular}

У групі щурів із видаленими гонадами каталазна активність у кірковому і мозковому шарах нирки через 1 місяць посттравматичного періоду, порівняно 3 контролем, теж знижувалася (відповідно на 35,1 та 35,8 \%, p<0,05) й залишалася на такому ж рівні до 2 місяця експерименту ( $>>0,05)$. Порівняння каталазної активності у кірковому і мозковому шарах нирки в ході посттравматичного періоду в тварин із видаленими гонадами показало, що через 1 місяць експерименту величина досліджуваного показника у мозковому шарі нирки була статистично вірогідно меншою, ніж у кірковому (на 14,8 \%, p<0,05), проте через 2 місяці відмінності були не істотними ( $>>0,05)$. Вони виявилися статистично не вірогідними ( $>>0,05)$.

Порівняння каталазної активності у кірковому шарі нирки залежно від наявності гонад показало, що величина досліджуваного показника за умов видалення гонад істотно не відрізнялася у контролі $\left(p_{1}>0,05\right)$, проте була істотно меншою через 1 і 2 місяці після моделювання краніоскелетної травми (відповідно на 31,4 та 43,3 \%, $\left.p_{1}<0,05\right)$. Водночас, у мозковому шарі нирки і в контролі й в усі досліджувані терміни посттравматичного періоду каталазна активність за умов видалення гонад була меншою (відповідно на 38,6; 30,7 та 57,1 \%, p <0,05).

Отримані результати свідчать про те, що у контролі без видалення гонад активність досліджуваних ензимів антиоксидантного захисту була більшою у мозковому шарі нирки, порівняно з кірковим, що виявилося статистично значущим за активністю каталази. Підвищена активність ензимів мозкового шару, порівняно 3 кірковим, очевидно пов'язана 3 вищими енергетичними потребами мозкового шару нирки, в канальцевому апараті якого відбувається активна реабсорбція компонентів первинної сечі [4].
Це створює передумови утворення АФО, посилення процесів ліпідної пероксидації й компенсаторного підвищення активності ензимів першої ланки, спрямованих на нейтралізацію АФО та їх метаболітів. Аналогічні результати отримані й іншими авторами $[4,5]$.

Проте звертає на себе увагу той фракт, що через 1 місяць після видалення гонад СОД- та каталазна активність у мозковому шарі нирки, навпаки, знижувалися. Це вказує на розвиток порушень антиоксидантного захисту тканин нирки й, очевидно, пов'язане зі зниженням вмісту естрогенів, яким притаманна фрізіологічна антиоксидантна дія [1].

Через 1 місяць посттравматичного періоду в тварин без гонадектомії СОД- і каталазна активність кіркового і мозкового шарів нирки істотно знижувалися порівняно $з$ контролем. Останнє, вірогідно, зумовлено впливом патогенних чинників травматичної хвороби (порушенням мікроциркуляції, розвитком гіпоксії, активізацією вільнорадикальних процесів) й зустрічається в ряді публікацій, присвячених дослідженню патогенетичних особливостей періоду пізніх проявів травматичної хвороби $[11,12]$. Через 2 місяці експерименту досліджувані ензими нормалізувалися, що вказує на домінування саногенних механізмів.

Нанесення травми гонадектомованим тваринам супроводжувалося більшим пригніченням СОД- і каталазної активності кіркового і мозкового шарів нирки через 1 місяць посттравматичного періоду. На такому ж рівні досліджувані ензими залишалися й через 2 місяці експерименту. В усі терміни після нанесення травми СОД- та каталазна активність були суттєво меншими в мозковому шарі нирки.

Отже, антиоксидантні властивості естрогенів відіграють вагому роль у патогенезі періоду пізніх 
прояві травматичної хвороби. Унаслідок видалення гонад і зниження фрізіологічного вмісту естрогенів настає більше виснаження чинників антиоксидантного захисту в фрункціональних шарах нирки, зумовлене краніоскелетною травмою. Виявлені порушення не стихають до 2 місяців експерименту, що необхідно враховувати при розробці заходів корекції травматичної хвороби за умов фрізіологічної чи клінічно зумовленої гіпоестрогенії. У перспективі варто дослідити ефективність гормональної замісної терапії у корекції виявлених порушень.

\section{СПИСОК ЛІТЕРАТУРИ}

1. Хара М. Р. Статеві відмінності метаболічних змін у міокарді щурів з експериментальним гіпотиреозом, викликаних гонадектомією та корегованих замісною гормонотерапією / М. Р. Хара, В. М. Михайлюк // Клінічна та експериментальна патологія. - 2012. - Т. XI, № 2 (40). - C 152-158.

2. Гур'єв С. О. Аналіз безпосередіх причин смерті у постраждалих із політравмою та пошкодженням скелета / С. О. Гур'єв, А. Ю. Філь, О. М. Танасієнко // Травма. 2015. - T. 16, № 4. - C. 7-10.

3. Борис Р. М. Морфологічні і біохімічні зміни внутрішніх органів при експериментальній краніоскелетній травмі : монографія / Р. М. Борис. - Тернопіль : Укрмедкнига, 2013. - 142 c.

4. Шацький В. В. Динаміка антиоксидантно-прооксидантного балансу кіркового і мозкового шарів нирки після гострої крововтрати, ускладненої ішемією-реперсузією кінцівки, та його корекція карбацетамом / В. В. Шацький, А. А. Гудима, Л. Я. Федонюк // Здобутки клініч. і експерим. медицини. - 2019. - № 4. - С. 144-153.

5. Мерлєв Д. І. Особливості антиоксидантно-прооксидантного стану кіркового шару нирки в умовах скелетної, черепно-мозкової травм та їх поєднання / Д. І. Мерлєв, А. А. Гудима // Здобутки клініч. і експерим. медицини. 2013. - № 2. - С. 140-142.

6. Машевський А. С. Особливості антиоксидантнопрооксидантного балансу у тканині печінки в пізній період після скелетної і поєднаної краніоскелетної травм в умовах оваріоектомії в щурів / А. С. Машевський // Вісник морської медицини. - 2016. - № 3. - С. 47-51.

7. Камышников В. С. Клинико-лабораторный мо-

\section{REFERENCES}

1. Khara MR, Mykhayliuk VM. [Sex differences in metabolic changes in the myocardium of rats with experimental hypothyroidism caused by gonadectomy and corrected with hormone replacement therapy]. Klinichna ta eksperymentalna patolohiia. 2012;XI;2(40): 152-8. Ukrainian.

2. Huryev SO, Fil AYu, Tanasiyenko OM. [Analysis of direct causes of death in victims with polytrauma and skeletal damage]. Travma. 2015;16(4): 7-10. Ukrainian.

3. Borys RM. [Morphological and biochemical changes of internal organs at experimental cranioskeletal trauma: monograph. [Морфологічні і біохімічні зміни внутрішніх органів при експериментальній краніоскелетній травмі: монографрія] Ternopil: Ukrmedknyha; 2013. Ukrainian.

4. Shatsky VV, Gudyma AA, Fedoniuk LYa. [Dynamics of

\section{вИСновки}

В умовах краніоскелетної травми через 1 місяць посттравматичного періоду в кірковому і мозковому шарах нирки відмічають порушення ензимної ланки антиоксидантного захисту, яке виявляють зниженням СОД- та каталазної активності порівняно 3 контролем. У гонадектомованих щурів виявлені порушення суттєво більші й не стихають через 2 місяці експерименту, що вказує на вагому роль антиоксидантної дії естрогенів у патогенезі травматичної хвороби.

ниторинг биохимических маркеров остеопороза в эксперименте / В. С. Камышников, Ю. Д. Коваленко, Н. Н. Кохнович // Достижения медицинской науки Беларуси [Електронний ресурс]. - 2003. - Режим доступу: http:// med.by/dmn/book.php?book=03-18_10.

8. Борис Р. М. Динаміка показників пероксидного окиснення ліпідів у період ранніх і пізніх проявів травматичної хвороби за умов експериментальної краніоскелетної травми та її корекції клітинною терапією / Р. М. Борис, А. І. Гоженко, А. А. Гудима // Клінічна та експериментальна патологія. - 2013. - Т. XII, № 2 (44). - С. 31-34.

9. Чевари С. Роль супероксиддисмутазы в окислительных процессах клетки и метод определения ее в биологических материалах / С. Чевари, И. Чаба, Й. Сокей // Лаб. дело. - 1985. - № 11. - С. 678-681.

10. Метод определения активности каталазы / М. А. Королюк, Л. И. Иванова, И. Г. Майорова, В. Е. Токарев // Лаб. дело. - 1988. - № 1. - С. 16-19.

11. Придруга С. М. Динаміка вмісту продуктів пероксидного окиснення ліпідів в печінці щурів у період пізніх проявів траватичної хвороби та корекції відхилень тіотриазоліном / С. М. Придруга // Вісник проблем біології і медицини. - 2012. - Т. 1, № 4. - С. 244-247.

12. Близнюк Р. В. Антиоксидантно-прооксидантний баланс у тканині печінки, кірковому та мозковому шарі нирки у тварин з хронічним гепатитом на тлі полі травми / Р. В. Близнюк, А. А. Гудима // Здобутки клініч. і експерим. медицини : підсумкова науково-практична конфреренція, 21 трав. 2014 р. : зб. матеріалів конф. - Тернопіль : ТДМУ, 2014. - C. 103.

antioxidant-prooxidant balance of renal cortex and medulla after acute blood loss complicated by ischemia-reperfusion of the extremity, and its correction with carbacetam]. Zdobutky klinichnoi i eksperymentalnoi medytsyny. 2019;4: 144-53. Available from: 10.11603/1811-2471.2019.v.i4.10815 Ukrainian.

5. Merlev DI, Hudyma AA. [Features of antioxidantprooxidant state of the renal cortex in the conditions of skeletal, craniocerebral injuries and their combination]. Zdobutky klinichnoi i eksperymentalnoi medytsyny. 2013;2: 140-2. Ukrainian.

6. Mashevskiy AS. [Features antioxidant-prooxidant balance in liver tissue late in skeletal after injury and combined kranioskeletal under ovariectomy in rats]. Visnyk morskoi medytsyny. 2016;3: 47-51. Ukrainian. 
7. Kamyshnikov VS, Kovalenko YuD, Kokhnovich NN. [Clinical and laboratory monitoring of biochemical markers of osteoporosis in the experiment]. Dostizheniya meditsinskoy nauki Belarusi. 2003. Available from: http://med.by/dmn/book. php?book=03-18_10. Russian.

8. Borys RM, Gozhenko Al, Gudyma AA. [The dynamics of lipid peroxidation indices during early and late manifestations of traumatic disease under conditions of experimental cranioskeletal injury and its correction by cell therapy]. Klinichna ta eksperymentalna patolohiya. 2013;XII:2(44): 31-4. Ukrainian.

9. Chevari S, Chaba I, Sokey Y. [The role of superoxide dismutase in the oxidative processes of the cell and the method for its determination in biological materials]. Laboratornoye delo. 1985;11: 678-81. Russian.
10. Korolyuk MA, Ivanova LI, Mayorova IG, Tokarev VYe. [Method for determining the activity of catalase]. Labolatornoye delo. 1988;1: 16-9. Russian.

11. Prydruha SM. [Dynamics of the content of lipid peroxidation products in the liver of rats during the late manifestations of traumatic disease and correction of deviations by thiotriazoline]. Bull Probl Biol Med. 2012;1;4: 244-7. Ukrainian.

12. Bliznyuk RV, Hudyma AA. [Antioxidant-prooxidant balance in liver tissue, cortical and cerebral layer of the kidney in animals with chronic hepatitis on the background of the field of injury]. Achievements of clinical and experimental medicine: final scientific-practical conference, May 21. Ternopil: TNMU; 2014. Ukrainian. 